\title{
THE IMPLEMENTATION OF PLANNING AND BUDGETING REDESIGN SYSTEM IN NATIONAL NUCLEAR ENERGY AGENCY
}

\author{
Nata Wijaya ${ }^{1}$, Ahmad Muntako
}

1) Biro Perencanaan - BATAN, Jakarta Selatan, Indonesia, nata-w@batan.go.id

2) Biro Perencanaan - BATAN, Jakarta Selatan, Indonesia, aburifqy@batan.go.id

\begin{abstract}
ABSTRAK
PENERAPAN REDESAIN SISTEM PERENCANAAN DAN PENGANGGARAN PADA BADAN TENAGA NUKLIR NASIONAL. Badan Tenaga Nuklir Nasional (BATAN) mulai menerapkan konsep redesain sistem perencanaan dan penganggaran (RSPP) pada penyusunan rencana kerja dan dokumen anggaran tahun 2021. Konsep RSPP ini mengubah nomenklatur program, kegiatan, dan keluaran BATAN yang diinput ke dalam aplikasi KRISNA. Konsep RSPP juga mengubah substansi dari program, kegiatan, dan keluaran sehingga berdampak pada komposisi anggaran masing-masing. Penerapan konsep RSPP diharapkan dapat memperkuat penerapan money follow program yang merupakan penyempurnaan dari konsep money follow function, sehingga pelaksanaan program dan kegiatan BATAN dapat berjalan dengan lebih baik dan sesuai peraturan perundang-undangan.
\end{abstract}

Kata kunci: anggaran, kegiatan, keluaran, perencanaan, program

\begin{abstract}
BATAN is presently applying the RSS concept of planning and budgeting redesign systems to prepare a work plan and budget document for 2021. This concept changes the nomenclature of programs, activities, and outputs that are input into the KRISNA. It also influences the substance of programs, activities, and outputs of each budget. The implementation of the RSPP concept is expected to strengthen the money follow program concept for the successful implementation of programs and activities in accordance with statutory regulations.
\end{abstract}

Keywords: activity, budget, output, planning, program

\section{INTRODUCTION}

The Indonesian government has continuously carried out reforms in the field of state planning and budgeting. Some of the significantly significant changes include redesigning the budget from input to output base. Efforts have been made to realize this, including (1) implementing a policy of programs and activities redesign in 2009, such as activities attached to Echelon I and II (money follow function), (2) applying the concept of Data Architecture and Performance Information (ADIK) to enhance the formulation of outputs and link them to outcomes, in accordance with the logical model framework, introduced in 2015 , (3) synchronization of the national development planning and budgeting process into the KRISNA information system (Planning Collaboration and Budget Performance
Information). This is to realize the implementation of the money follows program concept as a refinement of the function concept, which started in 2017.

There are several obstacles associated with evaluating the planning and budgeting system until the end of 2019. These include difficulty in understanding the performance information contained in planning and budgeting documents due to the formulation of indicators and the nomenclature of the program. Other factors include the use of normative activity names, the use of several unreal outputs, and the non-acceptance of the final product by society. These factors prompted the preparation of the Planning and Budgeting System Redesign (RSPP) for the 2021 fiscal year. This study is expected to address the weaknesses of the reforms developed and implemented previously. 
The National Nuclear Energy Agency (BATAN) as one of the Non-Ministerial Government Institutions under the Ministry of Research and Technology coordination in implementing the RSPP policy. The design of the new process started in 2020 by adjusting the data in the BATAN Work Plan using the KRISNA application. Data adjustment consists of adjusting the program data, activities, and outputs. This research discusses the implementation of the RSPP policy in the BATAN planning and budgeting in 2021.

\section{THEORY}

The RSPP concept aims to realize the implementation of the money follow program policy by strengthening the implementation of performance-based budgeting in accordance with the Joint Circular Letter (SEB) of the Minister of Finance and the Minister of National Development Planning [1]. This is carried out by aligning the nomenclature formulation of Programs, Activities, and Outputs that reflect "real work" (concrete). This is in addition to the application of value for money in the planning, budgeting, and implementation processes, as well as the preparation of performance information that is easily understood by the public.

The money follow program is a budgeting approach based on the weight of activities. It is also in accordance with the objectives set by the government to provide great benefits to the people [2]. This approach is expected to provide A HIGH-PRIORITY ALLOCATION SCALE FOR PROGRAMS THAT are beneficial to the community.

The concept of value for money (VFM) is a measurement of the use of the state budget for the community using economic, effective, and efficient indicators [3]. This is also interpreted as the process of spending less, well, and wisely to achieve local priorities [4]. Mardiasmo stated that economics is related to obtaining certain quality inputs at the lowest prices. Meanwhile, effectiveness is related to achieving outputs compared to the promised target, while efficiency is the process of achieving maximum output using certain inputs [5].
The SEB provisions are used to divide the scope of the RSPP into 3 attributes, namely redesigning the program, activities, and outputs of state agencies.

\section{Redesign Program}

The redesign program in the scope of the state ministries is a policy tool used to outline its duties and functions in accordance with the vision and mission of the President. This process is carried out by one or more Echelon I units. However, with the new redesign concept, the program no longer reflects the duties and functions of Echelon I units. This is due to the use of cross-echelon I units to carry out a similar vision and mission. The real implication is that there is a clear separation between programs with management (institutional services) and technical functions (external/community services).

\section{Activity Redesign}

The redesign of the ministries' scope is directed at the concepts of integration and convergence. Activities no longer reflect the duties and functions of the Echelon II Work Unit rather, they reflect on the activity carried out to produce outputs needed to support the realization of development goals. This concept allows more than 1 Echelon II Work Unit to carry out an activity, such as crossinstitution for generic activities. The programs and activities that function as management (institutional/generic internal services) are significantly separated from those that function technically (external/community services).

\section{Redesign Output}

The results of the activities are reflected in the output in the form of goods/services produced by the work unit. The redesign of the output scope of ministries/agencies is directed at the realignment concept by grouping similar outputs into a Classification of Output Details (KRO). This process aims to achieve an acceptable outcome of a program accepted by the customer outside the producing work unit. Furthermore, the units of these outputs are in uniform to ensure the formulations are prepared in accordance with the definitions, concepts, and scope of content as regulated in the legislation and in accordance with the duties 
and functions of the institution. Output at the institutional level, known as Detailed Output (RO), is specific and produced by a work unit focusing on a particular issue. It is also directly related to the tasks and supports the achievement of the predetermined activity targets.

Table 1. Differences between KRO and RO in the RSPP concept [1]

\begin{tabular}{ll}
\hline $\begin{array}{l}\text { Output Details } \\
\text { Classification (KRO) }\end{array}$ & Output Details (RO) \\
\hline Standardized and closed & Open, input from K/L \\
\hline $\begin{array}{l}\text { Houses or containers, not } \\
\text { real output }\end{array}$ & $\begin{array}{l}\text { The real output of work } \\
\text { units }\end{array}$ \\
\hline General in nature & Specific/unique includes loci \\
\hline Used by Many (All) K/L & $\begin{array}{l}\text { Reflecting the Tasks of the } \\
\text { Activity Implementing Unit }\end{array}$ \\
\hline Has units and volume & Has volume and units follow \\
& KRO \\
\hline
\end{tabular}

\section{METHODOLOGY}

This is a qualitative descriptive research carried out using the RSPP concept implementation to prepare the 2021 BATAN Work Plan (Renja) as a case study. Literature studies were conducted on papers, rules, and legislation related to state planning and budgeting. Secondary data were collected from the KRISNA-BAPPENAS Information System, which contains information, activities, KRO, and RO as the basis for the document.

Other this research other supporting data such as Online Services for the TreasuryMinistry of Finance, Laws and Presidential Regulations related to BATAN, Strategic Plan from 2020 to 2024.

\section{RESULTS AND DISCUSSION}

\section{Implementation of the RSPP in the BATAN Program}

The redesign of the BATAN program is carried out in 2 categories. The first is changing the nomenclature before implementing the RSPPusing Management Support Program, Implementation of Other Technical Tasks BATAN (DM), Research Program for Development, Application of Nuclear Energy, Isotopes and Radiation (Litbangrap ENISORA). After the implementation of the RSPP, the BATAN program became the Management
Support Program (DM) and the Science and Technology Research and Innovation Program (RI Iptek). Furthermore, DM and RI Iptek accommodate all internal and external service activities of BATAN, and R\&D, respectively. These 2 new programs are used by BATAN and other agencies that have $R \& D$ research and management support activities.

Table 2. Changes in the Nomenclature of the

\begin{tabular}{llll}
\multicolumn{3}{c}{ BATAN Program } \\
\hline 2017-2020 BATAN Program & $\begin{array}{l}\text { BATAN RSPP Program in } \\
\mathbf{2 0 2 1}\end{array}$ \\
\hline 1. $\begin{array}{l}\text { 1. Management } \\
\text { Support Program and } \\
\text { Other Technical } \\
\text { Implementation of } \\
\text { BATAN }\end{array}$ & 1. & $\begin{array}{l}\text { 1. Management } \\
\text { Support Program }\end{array}$ \\
\hline 2. $\quad \begin{array}{ll}\text { 2. Research Program } \\
\text { for the Development } \\
\text { and Application of } \\
\text { Nuclear Energy, } \\
\text { Isotopes and Radiation } \\
\text { (Litbangrap ENISORA) }\end{array}$ & 2. & $\begin{array}{l}\text { 2. Science Technology } \\
\text { Research and } \\
\text { Innovation Program (RI } \\
\text { Iptek) }\end{array}$ \\
\hline
\end{tabular}

The second aspect of program redesign at BATAN is the change in the composition of the budget between programs. This is due to the clear separation between the operational and supporting categories of budgets and those in the $R \& D$ category into their respective programs. The composition of the $R \& D$ program before the RSPP at BATAN throughout $2017-2020$ was $79-82 \%$ of the total BATAN budget. After implementing the RSPP, it became 22\%. However, the difference in the total amount of BATAN's budget was not much compared to previous years. After the implementation of the RSPP, more than $50 \%$ of BATAN's budget was absorbed to finance its office operations, which was also considered part of the BATAN R\&D program budget before the RSPP.

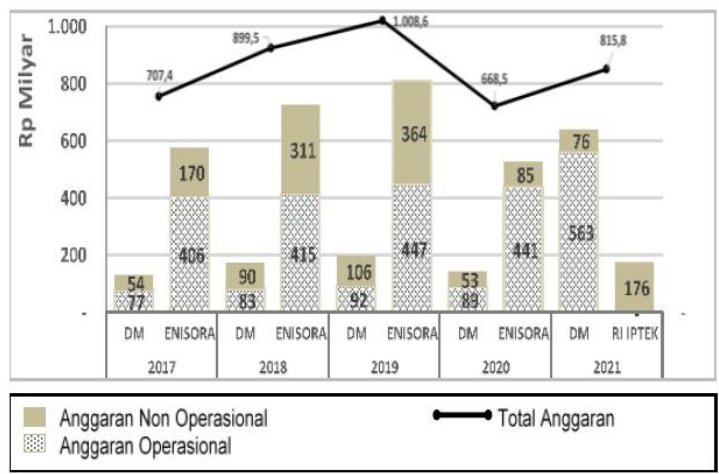

Figure 1. Composition of the BATAN program budget before and after the RSPP [6,7] 


\section{Implementation of RSPP in BATAN Activities}

The redesign of BATAN's activities is visualized in 2 aspects. The first is the change in the substance of the activity. The RSPP concept no longer makes the nomenclature of activities a reflection of Echelon II tasks, rather it reflects the activities carried out by the Work Unit to produce outputs by generic and technical activities. This tends to reformulate the nomenclature of BATAN activities based on the duties and functions with reference to Law Number 10 of 1997 concerning Nuclear Energy. It is also in accordance with Presidential Regulation Number 46 of 2013 and BATAN Regulation Number 6 of 2020 concerning the 2020-2024 BATAN Strategic Plans.

Table 3. References for the redesign of

BATAN's activities $[8,9,10]$

\begin{tabular}{|c|c|c|}
\hline UU 10/1997 & $\begin{array}{l}\text { Presidential } \\
\text { Decree 46/2013 }\end{array}$ & Perba 6/2020 \\
\hline Main Task & Task & $\begin{array}{l}\text { Strategic Area } \\
\text { Focus }\end{array}$ \\
\hline $\begin{array}{l}\text { - R\&D } \\
\text { - Production } \\
\text { and } \\
\text { manufacture } \\
\text { of nuclear fuel } \\
\text { - Radioactive } \\
\text { waste } \\
\text { management } \\
\text { - The general } \\
\text { investigation, } \\
\text { exploration, } \\
\text { and } \\
\text { exploitation of } \\
\text { nuclear } \\
\text { minerals } \\
\text { - Production of } \\
\text { radioisotopes } \\
\text { for R\&D } \\
\end{array}$ & $\begin{array}{l}\text { - Implementation } \\
\text { of nuclear } \\
\text { standardization } \\
\text { and quality } \\
\text { assurance } \\
\text { - training } \\
\text { - Facilitation and } \\
\text { guidance for } \\
\text { government } \\
\text { agencies and } \\
\text { other } \\
\text { institutions in } \\
\text { the field of } \\
\text { nuclear R\&D } \\
\text { and } \\
\text { development }\end{array}$ & $\begin{array}{l}\text { - Food/ } \\
\text { - Hgriculture } \\
\text { - Health } \\
\text { - Energy } \\
\text { - SDAL (Natural } \\
\text { Resources and } \\
\text { Environment) } \\
\text { - Advanced } \\
\text { - Material } \\
\text { - Engineering } \\
\text { - Safety and } \\
\text { - Security } \\
\text { - Institutional }\end{array}$ \\
\hline
\end{tabular}

Table 4. Formulation of the redesign of BATAN's activities [7]

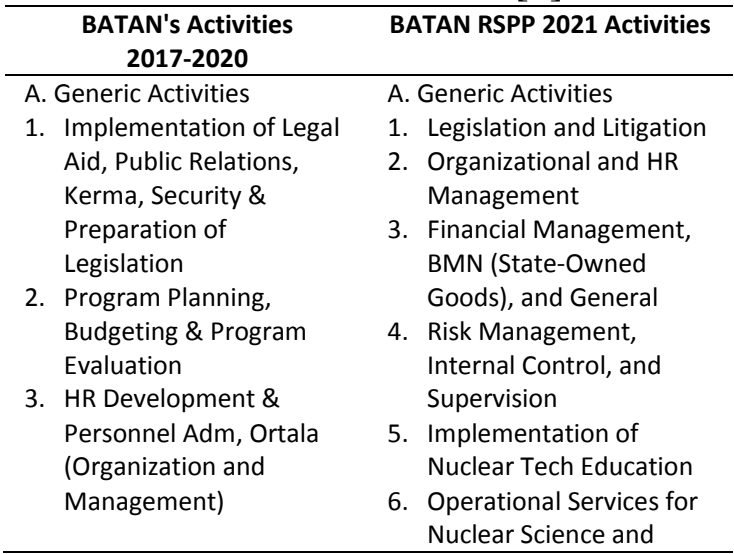

4. Financial, Equipment, Household \&

Administrative Management

5. Implementation of Apparatus Supervision \& Inspection

6. Implementation of BATAN Training

7. Implementation of Standardization, Nuclear Quality Assurance, Accreditation, and Certification

8. Implementation of Nuclear Tech Education

B. Technical Activities

1. R\&D Application of Isotopes and Radiation

2. Dissemination and Partnership of Nuclear Science and Technology Research and Development

3. Utilization of Informatics \& KSN

4. Assessment \& Application of Nuclear Energy Systems

5. Development of Exploration \& Management of Nuclear Minerals

6. Bangtek (Technical Development) Radioisotope and Radiopharmaceutical Production

7. Operation and Utilization of RSG (Multipurpose Reactor)

8. Nuclear Devices \& Facilities Engineering

9. Accelerator Science and Technology Development, Process Technology \& Research Reactor Management

10. Bangtek (Engineering Development) Nuclear Fuel

11. Development of Advanced Materials Science \& Technology with Nuclear Science and Technology

12. Development of Nuclear Biomedicine, Radioecology, Safety \& Radiation Metrology

13. Bangtek (Engineering Development) of Radioactive Waste Management

14. Development of Applied Nuclear Science \&

Technology \&

Revitalization of Research Reactors
B. Technical Activities

1. Nuclear Technology Research and Development for Innovation Products in the Food/Agriculture Sector

2. Nuclear Technology Innovation Research and Development in the Field of Safety

3. Bangjirap of Nuclear Technology for Environmental Management

4. Research and Development of Advanced Materials Based on Nuclear Science and Technology

5. Nuclear Devices \& Facilities Engineering

6. Nuclear \& Radiation Safety \& Security Technology Development and Assessment

7. Development and Assessment of Nuclear Fuel \& Reactor Technology

8. Development of Technological Innovation and Radioactive Waste Management

9. General Investigation Exploration, and Exploitation of Nuclear Minerals

10. Bangrap for Radioisotope \& Radiopharmaceutical Production Technology Innovation

11. Implementation of Nuclear Science and Technology Facilitation, Guidance, Services \& Guidance

12. Implementation of Standardization, Nuclear Quality Assurance, Accreditation \& Certification 
15. Bangtek (Engineering

Development) \& Nuclear

Reactor Safety

Changes in the substance of activities have led to many new activities at BATAN that are cross-echelon II. Furthermore, this shows the implementation of the concept of BATAN incorporated and encourages the re-formulation of R\&D activities targets that are more integrated and specific.

Table 5. R\&D Activities of BATAN 2021, which are cross-Working Units

\begin{tabular}{|c|c|}
\hline $\begin{array}{l}\text { BATAN's R\&D Activities in } 2021 \\
\text { which are Cross Work Units }\end{array}$ & Implementing Unit \\
\hline $\begin{array}{l}\text { 1. Implementation of the } \\
\text { Facilitation, Guidance, } \\
\text { Service and Technical } \\
\text { Guidance of Nuclear Science } \\
\text { and Technology }\end{array}$ & $\begin{array}{l}\text { PAIR, Pusdiklat (Education } \\
\text { and Training Center), } \\
\text { PTBGN, PTRR, PRSG, } \\
\text { PRFN, PSMN, PSTA, } \\
\text { PTBBN, PSTBM, PTKMR, } \\
\text { PTLR, PSTNT, PDK } \\
\text { (Coordinator) }\end{array}$ \\
\hline $\begin{array}{l}\text { 2. Development and } \\
\text { Assessment of Nuclear Fuel } \\
\text { and Reactor Technology }\end{array}$ & $\begin{array}{l}\text { PTBBN, PTKMR, PSTNT, } \\
\text { PTKRN, PKSEN } \\
\text { (Coordinator) }\end{array}$ \\
\hline $\begin{array}{l}\text { 3. Development and } \\
\text { Application of Radioisotope } \\
\text { and Radiopharmaceutical } \\
\text { Production Technology } \\
\text { Innovations }\end{array}$ & $\begin{array}{l}\text { PSTBM, PSTNT, PTRR } \\
\text { (Coordinator) }\end{array}$ \\
\hline $\begin{array}{l}\text { 4. Nuclear Devices and } \\
\text { Facilities Engineering }\end{array}$ & PAIR, PRFN (Coordinator) \\
\hline $\begin{array}{l}\text { 5. Research and Development } \\
\text { of Advanced Materials } \\
\text { Based on Nuclear Science } \\
\text { and Technology }\end{array}$ & $\begin{array}{l}\text { PTBGN, PSTA, PSTNT, } \\
\text { PSTBM (Coordinator) }\end{array}$ \\
\hline $\begin{array}{l}\text { 6. Research, Development, and } \\
\text { Application of Nuclear } \\
\text { Technology Innovations in } \\
\text { the Health Sector }\end{array}$ & $\begin{array}{l}\text { PSTBM, PSTNT, PAIR } \\
\text { (Coordinator) }\end{array}$ \\
\hline $\begin{array}{l}\text { 7. Development, Assessment, } \\
\text { and Application of Nuclear } \\
\text { Technology for } \\
\text { Environmental Management }\end{array}$ & $\begin{array}{l}\text { PSTBM, PSTNT, PAIR } \\
\text { (Coordinator) }\end{array}$ \\
\hline $\begin{array}{l}\text { 8. Development and } \\
\text { Assessment of Nuclear and } \\
\text { Radiation Safety and } \\
\text { Security Technology }\end{array}$ & $\begin{array}{l}\text { PPIKSN, PSTA, PTBBN, } \\
\text { PSTBM, PTKMR, PSTNT, } \\
\text { PTKRN, PRFN } \\
\text { (Coordinator) }\end{array}$ \\
\hline
\end{tabular}

The second aspect is the process of repositioning the Work Units (Satker) in the BATAN program. This tends to occur because BATAN activities' formulation results were categorized as technical, with numerous Supporting Work Units. Examples are service activities (PNBP) in the Education and Training Center (Pusdiklat) Work Unit, PSMN, and STTN. Conversely, some activities are categorized as generic and are carried out by the R\&D Work Unit. An example is the support activities for laboratories, infrastructure, and nuclear facilities. This is because there has been no change in the organizational structure of BATAN. Therefore, a solution is needed to map the activities carried out at BATAN, using a Work Unit with 3, namely a Management Support Program to accommodate generic activities, a Research and Development process, and Innovation Program to accommodate technical activities. This change also has an impact on the composition of the budget between programs and performance indicators.

Table 6. Repositioning of the Satker in the

\begin{tabular}{|c|c|}
\hline Satker BATAN 2017-2020 & Satker BATAN RSPP 2021 \\
\hline $\begin{array}{l}\text { A.Management Support } \\
\text { Program } \\
\text { (Head Office, } \\
\text { Inspectorate, Training } \\
\text { Center, PSMN, STTN) } \\
\text { 5 Satker }\end{array}$ & $\begin{array}{l}\text { A. Support Program } \\
\text { Management } \\
\text { (Head Office, } \\
\text { Inspectorate, Education } \\
\text { and Training Center, } \\
\text { PSMN, PTRR, STTN, } \\
\text { PRSG, PRFN, PSTA, } \\
\text { PTBBN, PAIR, PSTBM, } \\
\text { PDK, PTKMR, PPIKSN, } \\
\text { PTLR, PKSEN, PSTNT, } \\
\text { PTBGN, PTKRN) } \\
\text { 20 Satker }\end{array}$ \\
\hline $\begin{array}{l}\text { A. } \\
\text { ENISORA R\&D } \\
\text { (PAIR, PDK, PSTBM, } \\
\text { PPIKSN, PTKMR, PKSEN, } \\
\text { PTLR, PTBGN, PSTNT, } \\
\text { PTRR, PTKRN, PRSG, } \\
\text { PRFN, PSTA, PTBBN) } \\
15 \text { Satker }\end{array}$ & $\begin{array}{l}\text { B. RI Iptek Program } \\
\text { (PAIR, PDK, PSTBM, } \\
\text { PPIKSN, PTKMR, PKSEN, } \\
\text { PTLR, PTBGN, PSTNT, } \\
\text { PTRR, PTKRN, PRSG, } \\
\text { PRFN, PSTA, PTBBN, } \\
\text { PSMN, Education and } \\
\text { Training Cente } \\
\text { (Pusdiklat) } \\
\text { 17 Satker }\end{array}$ \\
\hline
\end{tabular}

\section{Implementation of RSPP on BATAN's Output}

The redesign of BATAN's output is visualized in changes to the Output structure. With the standardization of KRO (Output level), the output functions as a container at the RO level. This causes all BATAN's real output to appear as RO at the output and sub-output levels. Therefore, the number of BATAN suboutputs increases, with a decrease in KRO.

Table 7. Implications of the RSPP on the number of outputs and sub-outputs of

$$
\text { BATAN }
$$

\begin{tabular}{l|l}
\hline DIPA BATAN 2020 & DIPA BATAN RSPP 2021 \\
\hline B. Management Support & C. Management Support \\
Program & Program \\
\begin{tabular}{ll} 
1. Number of Output: & 1. Number of Outputs: \\
29 & 21 \\
\hline
\end{tabular}
\end{tabular}




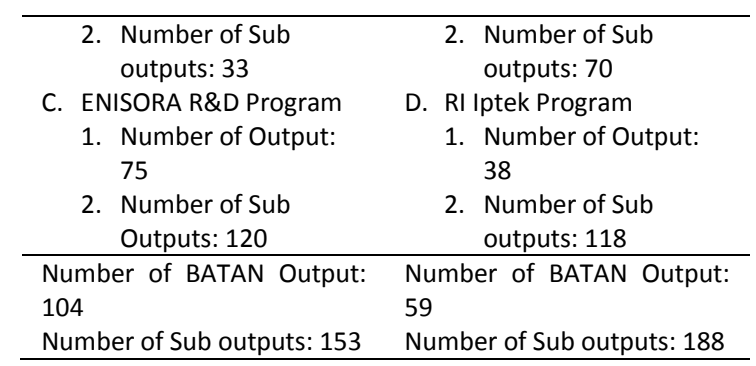

The RO and KRO units are standardized. Some RO BATAN have targets that will only be achieved in the long term therefore, the RO units do not match the real output. Some of the solutions for RO with long-term achievement targets need to be shown in its indicator.

Table 8. Examples of Application of Indicators to Long-Term Real Output

\begin{tabular}{|c|c|c|}
\hline KRO (Output Unit) & RO (target and unit) & $\begin{array}{l}\text { Indicator } \\
\text { Writing } \\
\text { (actual target } \\
\text { in 2021) } \\
\end{array}$ \\
\hline $\begin{array}{l}\text { Prototype } \\
\text { Research and } \\
\text { Development }\end{array}$ & $\begin{array}{l}\text { Power Reactor } \\
\text { Nuclear Fuel } \\
\text { Prototype (1 } \\
\text { Prototype) }\end{array}$ & $\begin{array}{l}\text { Number of } \\
\text { technical } \\
\text { documents } \\
\text { for the non- } \\
\text { destructive } \\
\text { and } \\
\text { destructive } \\
\text { test of } \\
\text { U3Si2/Al fuel } \\
\text { elements } \\
\text { post- } \\
\text { irradiation } \\
\text { burnup 20\% } \\
\text { test (1 } \\
\text { technical } \\
\text { document) }\end{array}$ \\
\hline $\begin{array}{l}\text { Nuclear Energy } \\
\text { Sector Policy } \\
\text { (policy } \\
\text { recommendations } \\
\text { ) }\end{array}$ & $\begin{array}{l}\text { Recommendation } \\
\text { for Characterization } \\
\text { of Radioisotope and } \\
\text { Radiopharmaceutica } \\
\text { I Products for } \\
\text { Diagnosis and } \\
\text { Therapy (1 policy } \\
\text { recommendation) }\end{array}$ & $\begin{array}{l}\text { Total research } \\
\text { data on } \\
\text { characteristic } \\
\text { s of RI-RF } \\
\text { products for } \\
\text { therapeutic } \\
\text { diagnosis } \\
\text { (HSA } \\
\text { nanocolloids, } \\
\text { mesoporous } \\
\text { gamma- } \\
\text { alumina, and } \\
\text { Gd } \\
\text { nanoparticles) } \\
\text { that have } \\
\text { been } \\
\text { validated on a } \\
\text { lab-scale (1 } \\
\text { research } \\
\text { data) }\end{array}$ \\
\hline
\end{tabular}

\section{Implementation of Money Follow Program}

In the Regulation of the Minister of Research and Technology on National Research Priorities (PRN) from 2020 to 2024 comprises of 3 research topics, namely preparation of the construction of commercial-scale nuclear power plants, production of raw materials for radioisotope drugs and radiopharmaceuticals, and radiation monitoring system technology for safety and security. Furthermore, BATAN supports 15 research topics with a focus on food, energy, health, transportation, engineering, and cross-sectoral multidisciplinary research [11]. The composition of the budget for PRN output is $84.04 \%$ of the RI Science and Technology program. This shows that there is a funding priority scale on outputs included in government programs as a form of implementing the Money Follow Program concept at BATAN.

\section{CONCLUSION}

In conclusion, the RSPP concept was implemented by BATAN in planning and budgeting for 2021. This is marked by the redesign of BATAN's programs, activities, and outputs. Furthermore, the implementation of the RSPP has implications for the recomposition of program and activity budgets. This is in addition to its impact on changes in the nomenclature and substance of programs, activities, and outputs also. The money follows program has been implemented at BATAN through priority budgeting on the output, which is part of government programs through PRN.

It is recommended the review of targets and performance indicators of activities that are cross-work units to clarify the role of each work unit. Further studies need to be conducted to examine the possibility of changing the BATAN organization due to the implementation of the RSPP, which changes the composition of the budget in the Work Unit.

\section{ACKNOWLEDGMENT}

The authors are grateful to Allah ta'ala and Mr. Ferly Hermana, Head of the Planning Bureau, Mr. Budi K, Wachid, Retin, Dian, and Ega as colleagues in the Budgeting Section. The authors are also grateful to Mr. Thomi, Mr. Imawan, Mrs. Ninik and Yogi, family, and BP's 
friends for their cooperation, support, and prayers.

\section{REFERENCES}

1. Surat Edara Bersama (SEB), Pedoman Redesain Sistem Perencanaan dan Penganggaran, $S-122 / M K .2 / 2020, \quad B$ 517/M.PPN/D.8/PP.04.03/05/2020, Jakarta 2020.

2. Silvia Ningsih, "Analisis Penerapan Anggaran Berbasis Kinerja dengan Konsep Money Follow Program Dalam Perencanaan dan Penganggaran Kota Padang", Jurnal Akuntansi \& Manajemen, vol. 13(1), pp. 1-6, 2018.

3. Deddi Nordiawan, 2010. Akuntansi Sektor Publik, Jakarta: Salemba Empat.

4. Barnett C, Final Report: Measuring the Impact and Value for Money of Governance \& Conflict Programmes, ITAD 2010.

5. Mardiasmo, 2009. Akuntansi Sektor Publik, Yogyakarta: Penerbit Andi.

6. KEMENKEU, "Layanan Online Perbendaharaan", https://spanint.kemenkeu.go.id, accessed on 20 Oktober 2020.

7. BAPPENAS, "Kolaborasi Perencanaan dan Informasi Kinerja". https://batan.kl.krisna.systems/renjak1/2021 /home, accessed on 20 Oktober 2020

8. Nuclear Law No. 10/1997, Supplement to the State Gazette Number 3676, 1997.

9. Presidential Regulation about BATAN No. 46/2013, State Gazette Number 113, 2013.

10. BATAN Regulation on the 2020-2024 about BATAN Strategic Plan No. 6/2020, State Gazette of the Republic of Indonesia Number 671, 2020.

11. Minister of Research, Technology and Higher Education Regulation about National Research Priorities for 2020-2024 No. 38/2019, State Gazette of the Republic of Indonesia Number 1269, 2019. 
Jurnal Forum Nuklir, Volume 15, Nomor 1, Mei 2021 